\title{
Factors Associated To Breastfeeding Cessation Before 6 Months
}

\author{
Antoni Oliver Roig ${ }^{1}$ \\ Miguel Richart Martínez² \\ Julio Cabrero García ${ }^{2}$ \\ Santiago Pérez Hoyos ${ }^{3}$ \\ Ginesa Laguna Navidad ${ }^{4}$ \\ Juan Carlos Flores Álvarez ${ }^{5}$ \\ María del Mar Calatayud Pujalte ${ }^{6}$ \\ Ricardo García de León González ${ }^{7}$
}

This research aimed to identify the determinants of full breastfeeding (FBF) and any breastfeeding ( $A B F$ ) cessation before 6 months, through a six-month follow-up of 248 mothers going a postpartum visit. Data were collected by personal interview during the first month and telephone interviews at four and six months postpartum. Cox's proportional hazards model was used. Not having previous ABF experience, previous ABF duration $\leq 4$ months and worse evaluation of previous experience were associated with cessation of $A B F$ and FBF. Lower educational level was associated with cessation of $A B F$ and the use of pacifiers or occasional breast-milk substitutes with cessation of FBF. Attending childbirth education was a protective factor against early FBF or ABF cessation. Activities supporting breastfeeding should be intensified for mothers with poorer access to information and with negative or without ABF previous experience. The use of pacifiers and not-medically indicated breast milk substitutes should be controlled.

Descriptors: Breast Feeding; Weaning; Follow up Studies; Epidemiologic Factors.

\footnotetext{
${ }^{1}$ M.Sc. in Nursing Sciences. Departamento de Enfermería, Universidad de Alicante, España. E-mail: antonio.oliver@ua.es.

2 Full Professor, Escuela Universitaria, Departamento de Enfermería, Universidad de Alicante, España. E-mail: m.richart@ua.es. E-mail: julio.cabrero@ua.es.

${ }^{3}$ Unidad de Epidemiología y Estadística, Escuela Valenciana de Estudios de la Salud, España. E-mail: santi.perezhoyos@cresib.cat.

${ }^{4}$ RN. Departamento de Salud de Elda, Hospital General de Elda, España. E-mail: ginesalaguna@hotmail.com.

${ }^{5}$ Midwife, Departamento de Salud de Elda, Hospital General de Elda, España. E-mail: jcflores@matronmonovar.jazztel.es.

${ }^{6}$ Midwife, Departamento de Salud de Elda, Hospital General de Elda, España. E-mail: mmcalatayud@gmail.com.

7 Pediatrician. Hospital "Virgen del Castillo" de Tecla, España. E-mail: ricardo.garciadeleon@carm.es.
}

\author{
Corresponding Author: \\ Antoni Oliver Roig \\ Universidad de Alicante. Departamento de Enfermería \\ Apdo. Correos 99 \\ Alicante \\ 03080 \\ España \\ E-mail: Antonio.Oliver@ua.es
}




\section{Fatores associados ao abandono do aleitamento materno durante os primeiros seis meses de vida}

O objetivo da pesquisa foi identificar os fatores associados ao abandono do aleitamento materno (AM) e do aleitamento materno completo (AMC). Foram acompanhadas 248 mães que fizeram visita pós-parto. Os dados foram coletados mediante entrevista pessoal durante o primeiro mês pós-parto e, pelo telefone, aos quatro e seis meses seguintes. A análise se realizou mediante a Regressão de Cox. Os resultados mostram associação entre o abandono da AMC e do AM com o fato de não se ter amamentado anteriormente, com AM anterior $\leq 4$ meses, e, com pior avaliação da experiência anterior. O menor nível de estudos se relaciona com maior abandono do AM e das chupetas, ou suplementos no hospital com o abandono da AMC. A educação pré-natal é fator protetor para o AMC e o AM. Conclui-se que o apoio ao AM deveria intensificar-se nas mães: sem experiência anterior, com experiência negativa, e, com pior acesso à informação; também deveria ser controlado o uso da chupeta e dos suplementos de leite artificial (LA) não indicados.

Descritores: Aleitamento Materno; Desmame; Seguimentos; Fatores Epidemiológicos.

\section{Factores asociados al abandono de la lactancia materna durante los primeros 6 meses de vida}

El objetivo de la investigación fue identificar los factores asociados al abandono de la lactancia materna (LM) y de la lactancia materna completa (LMC). Fueron acompañadas 248 madres que acudieron a la visita posparto. Los datos fueron recolectados mediante entrevista personal durante el primer mes posparto y por teléfono a los cuatro y seis meses siguientes. El análisis se realizó mediante la Regresión de Cox. Los resultados muestran una asociación con el abandono de la LMC y de la LM con no haber amamantado anteriormente, con LM anterior $\leq 4$ meses, y, con una peor valoración de la experiencia anterior. El menor nivel de estudios se relaciona con un mayor abandono de la LM y los chupetes o suplementos en el hospital con el abandono de la LMC. La educación prenatal es un factor protector para la LMC y la LM. Se concluye que el apoyo a la LM debería intensificarse las madres: sin experiencia anterior, con experiencia negativa, $y$, con peor acceso a la información; también debería controlarse el uso de chupetes y suplementos de leche artificial (LA) no indicados.

Descriptores: Lactancia Materna; Destete; Estudios de seguimiento; Factores Epidemiológicos.

\section{Introduction}

Breastfeeding (BF) benefits mothers' and infants' health in the short and long terms and is the most adequate option to feed infants. The World Health Organization recommends exclusive breastfeeding during the first six months of life and combined with complementary foods until the age of two years or older, but only a minority of European infants, including the Spanish, are breastfed in accordance with these recommendations ${ }^{(1)}$.
The duration of BF has been positively associated with age, education level and the mother's earlier BF experience $^{(2-3)}$ and negatively with the infant's low birth weight ${ }^{(4)}$, c-section ${ }^{(2,4)}$, breastfeeding problems ${ }^{(5)}$, negative family attitude towards $\mathrm{BF}^{(5)}$ and the mother's inclusion in paid work ${ }^{(2,4-6)}$.

Specific professional support and peer interventions ${ }^{(7)}$, adequate information access $^{(6)}$ and the implementation of the 10 steps of the Baby-Friendly 
Hospital Initiative $(\mathrm{BFHI})^{(8)}$ in hospitals in general have shown their efficacy to improve BF rates.

Most Spanish research about factors related to BF duration resulted from cross-sectional data $(4,9)$ or focused on factors determining $\mathrm{BF}$ prevalence at concrete moments during follow-up(6) and do not use definitions of BF types based on the classification proposed by $\mathrm{WHO}^{(10)}$, which impairs the adequate interpretation and comparison among results. Only one pilot study ${ }^{(2)}$ carried out in Spain complies with these two conditions.

This research aims to determine the independent effect of factors related to the duration of Full BF (FBF) and Any BF (ABF) during the first six months of life in a Spanish population.

\section{Material and Methods}

\section{Participants}

The study population included the mother-infant pairs in Elda (Spain). Elda is a city with 55,174 inhabitants (National Statistics Institute) and its economy is mainly based on the footwear industry.

The sample included all women who had offered BF after birth and consulted one out of four primary care midwifes in Elda between March 2002 and March 2003. Mothers whose infants obtained a five-minute APGAR score $<6$, weight $<2500 \mathrm{~g}$, congenital disease processes or perinatal or posterior death, gestational age $<37$ weeks or who did not start BF after birth.

The study sample comprised 270 mother-infant pairs, supposing $76 \%$ of births in Elda in $2003(n=353)$. The remaining $24 \%$ include, besides cases with some exclusion criterion, mothers who did not consult the midwife or who did during the replacement period of one of the participating midwives.

\section{Methods}

After obtaining informed consent, a six-month follow-up was carried out. Antecedent variables included information about socioeconomic characteristics and maternal antecedents like age, marital status, education level and family social class. To determine the family social class, the highest value for the class was obtained, based on the mother's and her partner's occupation, using the 1994 National Classification of Occupations and registering the equivalent to the British classification of social classes ${ }^{(11)}$.

The following were also included as antecedent variables: obstetric aspects (parity, delivery type, infant's gender and weight), whether the infant was hospitalized at the Neonatal Intensive Care Unit and previous BF experience, valuation and duration of previous BF experience, participation in a prenatal education group and expected BF time.

Other antecedent variables included hospital routines, such as skin-to-skin contact with the infant after birth, rooming-in practice, pacifier use, occasional use of breast milk substitutes, limitation of breastfeeding duration and frequency and variables related to professional support, such as having received specific help for BF in hospital or recommendations to reduce or abandon BF and infant formula (IF) sample gifts after discharge. Family conditions and support, such as the partner's collaboration in housework and the number of people younger than five years or disabled people who depended on the woman's care were considered as antecedent variables.

Outcome variables included time until cessation of FBF and $A B F$ or until abandoning the study because followup of the case was lost or if the FBF or ABF continued for more than 180 days. The description of the infants' food is based on the definitions proposed by $\mathrm{WHO}^{(10)}$. The duration of FBF was considered to be the time until the introduction of IF or complementary feeding (CF) and duration of $A B F$ as the time during which the infants received any quantity of mother's milk.

Data were collected through a personal interview during the midwifery consultation upon the mother's first postpartum visit (antecedent variables), during the infant's first month of life, and through telephone interviews at four and six months postpartum (outcome variables) for mothers who continued ABF during the last contact. Moreover, during the fourth month postpartum, information was collected about the type of maternity leave chosen, return to the paid job and satisfaction with family cooperation in housework during the first month postpartum.

\section{Data analysis}

Variables were subject to descriptive analysis, calculating proportions, means and standard deviations (SD).

To detect differences in antecedent variables between the sample with complete follow-up and the sample with censored data before the age of six months, Student's t-test was used for continuous variables and $\mathrm{X}^{2}$ for categorical variables.

To obtain the explanatory models for FBF and ABF duration, variables were subject to a first selection through individual analysis, using comparison of Kaplan- 
Meier curves for categorical variables (Mantel-Cox tests) and univariate Cox regression for continuous variables. In the multivariate models, all variables associated with FBF or $A B F$ were included, with $p<0.05$ in bivariate analysis.

Cox regression models were developed to determine associated variables, independently of the duration of FBF and $A B F$, using a sequential stepwise backward model, selecting the optimal set of variables by means of the likelihood ratio test. The existence of possible confounding factors or multiplicative interactions was discarded by observing a significant change in the likelihood logarithm after introducing the factor or interaction into the models (manual method). To confirm the supposed proportionality of hazards, the significance of including the term of each variable's interaction with the logarithm of follow-up time was contrasted.

The "expected BF time" variable was not included in the models as this factor does not influence the decision to cease BF but is part of the decision itself(12). The introduction (not occasional) of IF or complementary feeding was not included as a factor either, since it cannot be considered a risk factor for the abandonment of $A B F$, as it is an intermediary step necessary for the complete cessation of BF.

The effect of the antecedent variables was described as the Hazard Ratio (HR). Confidence intervals were calculated for a $95 \%$ confidence level. Stata/SE for Windows v. 9.0 was used for calculations.

\section{Results}

\section{Sample characteristics and breastfeeding duration}

Data about the study variables were collected from 248 mother-infant pairs; one mother decided not to participate in the research and, in 21 cases, data were obtained about the evolution of breastfeeding only. No statistically significant differences were observed between the sample with complete follow-up and the sample with censored values before the end of FBF $(10 \%, n=25)$ or $\operatorname{ABF}(14.5 \%, n=36)$ follow-up.

The mothers' mean age was 30.4 years (Standard Deviation (SD) 4.6). The infants' mean birth weight was 3287 grams (SD 357.6). In the first results column of Table 1, sample characteristics are shown.

The percentage of mothers offering breastfeeding at 30,90 and 180 days was $67.7 \%(n=168), 58.1 \%$ $(n=144)$ and $12.5 \%(n=31)$ and ABF $80.6 \%(n=200)$, $70.6 \%(n=175)$ and $38.3 \%(n=92)$ respectively.

\section{Bivariate and multivariate analysis}

The results of the bivariate analysis are shown in Table 1. No relation was found between FBF or ABF cessation and the mother's age or the baby's birth weight.

Table 1 - Total duration of FBF and ABF according to antecedent variables

\begin{tabular}{|c|c|c|c|c|}
\hline Variables & Categories & n (\%) & FBF Sig $^{a}$ & ABF Sigb \\
\hline \multicolumn{5}{|l|}{ Socio-demographic antecedents } \\
\hline \multirow[t]{2}{*}{ Marital status } & Married/with partner & $239(96.5)$ & & \\
\hline & No partner & $9(3.5)$ & $0.03^{c}$ & $0.013^{c}$ \\
\hline \multirow[t]{2}{*}{ Study level } & Finished primary education & $166(66.9)$ & & \\
\hline & > primary education & $82(33.1)$ & $0.04^{d}$ & $<0.001^{c}$ \\
\hline \multirow[t]{3}{*}{ Family's social class } & Groups I to III & $110(44.5)$ & & \\
\hline & Groups IV and Vf & $137(55.5)$ & ns & ns \\
\hline & Did not answer & 1 & & \\
\hline \multicolumn{5}{|l|}{ Obstetric/breastfeeding antecedents } \\
\hline \multirow[t]{2}{*}{ Parity } & Primiparous & $138(55.6)$ & & \\
\hline & 1 or more previous children & $110(44.4)$ & ns & ns \\
\hline \multirow[t]{2}{*}{ Maternal education } & Yes & $196(79.0)$ & & \\
\hline & No & $52(20.9)$ & $0.003^{c}$ & $0.02^{\mathrm{c}}$ \\
\hline \multirow[t]{2}{*}{ Delivery Type } & Vaginal & $201(81.1)$ & & \\
\hline & C-section & $47(18.9)$ & ns & ns \\
\hline \multirow[t]{2}{*}{ Gender of baby } & Male & $128(51.6)$ & & \\
\hline & Female & $120(48.4)$ & ns & ns \\
\hline \multirow[t]{2}{*}{ Infant's entry in NICU } & Yes & $13(5.2)$ & & \\
\hline & No & $235(94.8)$ & ns & ns \\
\hline \multirow[t]{4}{*}{ Previous BF } & No previous BF & $145(58.9)$ & & \\
\hline & 4 months or $<$ & $56(22.8)$ & & \\
\hline & 5 months or $>$ & $45(18.3)$ & $<0.001^{\mathrm{c}}$ & $<0.001^{c}$ \\
\hline & Did not know/answer & 2 & & \\
\hline
\end{tabular}


Table 1 - Continuation

\begin{tabular}{|c|c|c|c|c|}
\hline Variables & Categories & n (\%) & FBF Siga & ABF Sig ${ }^{b}$ \\
\hline \multirow[t]{4}{*}{ Valuation of previous BF } & No previous BF & $145(58.9)$ & & \\
\hline & Not, somewhat or quite positive & $57(22.8)$ & & \\
\hline & Very positive & $44(18.3)$ & $<0.001^{c}$ & $0.001^{\mathrm{d}}$ \\
\hline & Did not know/answer & 2 & & \\
\hline \multirow[t]{4}{*}{ Planned BF time } & 3 or 4 months & $35(15.3)$ & & \\
\hline & 5 months & $14(6.1)$ & & \\
\hline & 6 months or more & $180(78.6)$ & $0.006^{c}$ & $0.003^{c}$ \\
\hline & Did not answer & 19 & & \\
\hline \multicolumn{5}{|l|}{ Hospital Routines/Professional Support } \\
\hline \multirow[t]{3}{*}{ Pacifier use at the hospital } & Yes & $79(32)$ & & \\
\hline & No & $168(68)$ & $0.008^{\mathrm{d}}$ & $0.03^{d}$ \\
\hline & Did not answer & 1 & & \\
\hline \multirow[t]{2}{*}{ Breast milk substitutes (hospital) } & Yes & $100(40.3)$ & & \\
\hline & No & $148(59.7)$ & $<.001^{\mathrm{c}}$ & ns \\
\hline \multirow[t]{2}{*}{ Breastfeeding frequency (hospital) } & Upon demand & $236(95.2)$ & & \\
\hline & At set hours & $12(4.8)$ & ns & ns \\
\hline \multirow[t]{2}{*}{ Duration of breastfeeding (hospital) } & No time restriction & $228(91.9)$ & & \\
\hline & With time restriction & $20(8.1)$ & ns & ns \\
\hline \multirow[t]{2}{*}{ Skin-to-skin contact postpartum } & During the first hour & $191(77)$ & & \\
\hline & After the first hour & $57(23)$ & ns & ns \\
\hline \multirow[t]{2}{*}{ Separation >1 hour (hospital) } & Yes & $17(6.8)$ & & \\
\hline & No & $231(93.2)$ & ns & ns \\
\hline \multirow[t]{3}{*}{ Help for BF (hospital) } & Yes & $120(48.6)$ & & \\
\hline & No & $127(51.4)$ & ns & ns \\
\hline & Did not answer & 1 & & \\
\hline \multirow{3}{*}{$\begin{array}{l}\text { Recommendations to reduce or abandon BF after } \\
\text { discharge }\end{array}$} & Yes & $25(10.5)$ & ns & ns \\
\hline & No & $214(89.5)$ & & \\
\hline & Did not answer & 9 & & \\
\hline \multirow[t]{3}{*}{ IF sample gifts after discharge } & Yes & $38(15.4)$ & ns & ns \\
\hline & No & $209(84.6)$ & & \\
\hline & Did not answer & 1 & & \\
\hline \multicolumn{5}{|l|}{ Family Conditions/Support } \\
\hline \multirow[t]{2}{*}{ Care for dependent people ${ }^{g}$} & None & $191(77)$ & & \\
\hline & One or more & $57(23)$ & ns & ns \\
\hline \multirow[t]{3}{*}{ Shares housework (Partner) } & Yes & $190(77.5)$ & & \\
\hline & No & $55(22.5)$ & $0.031^{\mathrm{d}}$ & $0.023^{\mathrm{d}}$ \\
\hline & Did not answer & 3 & & \\
\hline \multirow[t]{3}{*}{ Satisfaction with family cooperation in housework } & Strongly disagrees, disagrees or indifferent & $22(10.5)$ & & \\
\hline & Agrees or strongly agrees & $187(89.5)$ & ns & ns \\
\hline & Did not answer & 39 & & \\
\hline \multirow[t]{8}{*}{ Elected maternity leave } & Housewife or no remunerated job & $100(48.3)$ & & \\
\hline & Requested leave & $32(15.4)$ & & \\
\hline & Worked before 16 weeks & $7(3.4)$ & & \\
\hline & 16 weeks and work journey reduction & $5(2.4)$ & & \\
\hline & 16 weeks only & $43(20.8)$ & & \\
\hline & Breastfeeding permit ( 1 hour per day) & $12(5.8)$ & & \\
\hline & Work journey reduction & $8(3.9)$ & ns & ns \\
\hline & Did not answer & 41 & & \\
\hline
\end{tabular}

a Statistical significance of intergroup difference for FBF cessation (ns=not significant);

b Statistical significance of intergroup difference for ABF cessation (ns=not significant);

'Log Rank Test;

'Breslow Test;

e Managers, freelancers, supervisors, management support);

$\mathrm{f}$ Manual and unqualified workers;

${ }^{9}$ People $<5$ years or disabled who depend on woman's care (without counting the last child) 
The multivariate analysis was restricted to those mother-infant pairs with complete data for all research variables $(n=246)$. The explanatory models for the duration of FBF and ABF are shown in Table 2. Not having breastfed a child before is the variable with the greatest hazard for FBF cessation or ABF cessation, followed by having breastfed 4 months or less. Mothers who valued earlier breastfeeding as "very positive" breastfeed more than those who valued it as "not, somewhat or quite positive". Participating in maternal education sessions during pregnancy is a protective factor for FBF and ABF. Lower education level is associated with faster cessation of ABF; and occasional breast milk substitutes or pacifier use with FBF cessation. The Cox models' supposition of proportional hazards was confirmed and no interaction was found among the variables included in the models.

Table 2 - Factors Associated with FBF and BF cessation before 6 months $(n=246) *$

\begin{tabular}{|c|c|c|}
\hline \multirow{3}{*}{ Variables } & \multirow{2}{*}{$\frac{\text { END FBF }^{\mathrm{a}}}{\mathrm{HR}^{\mathrm{b}}}$} & END $A B F^{b}$ \\
\hline & & $\mathrm{HR}^{\mathrm{b}}$ \\
\hline & $\mathrm{Cl} 95 \%{ }^{\mathrm{c}}$ & $\mathrm{Cl} 95 \%^{\mathrm{c}}$ \\
\hline \multicolumn{3}{|l|}{ Socio-demographic, Obstetric, Breastfeeding Antecedents and } \\
\hline \multicolumn{3}{|l|}{ Family Conditions/Support } \\
\hline Civil status & ns & ns \\
\hline \multicolumn{3}{|l|}{ Education level } \\
\hline Finished primary education & ns & $2,00(1,27-3,15)$ \\
\hline >primary education & & 1 \\
\hline \multicolumn{3}{|l|}{ Previous Breastfeeding } \\
\hline No previous breastfeeding or first child & $4.44(2.60-7.58)$ & $6,21(2,72-14,17)$ \\
\hline Previous breastfeeding $\leq 4$ months & $2.62(1.56-4.37)$ & $3,67(1,75-7,72)$ \\
\hline Previous breastfeeding $>4$ months & 1 & 1 \\
\hline No, somewhat or quite positive previous breastfeeding & $2.04(1.24-3.36)$ & $2,02(1,04-3,91)$ \\
\hline Very positive previous breastfeeding & 1 & 1 \\
\hline \multicolumn{3}{|l|}{ Maternal educational assistance } \\
\hline Yes & $0.41(0.28-0.61)$ & $0,46(0,23-0,73)$ \\
\hline No & 1 & 1 \\
\hline Shares housework with partner & ns & ns \\
\hline \multicolumn{3}{|l|}{ Hospital Routines and Professional Support } \\
\hline \multicolumn{3}{|l|}{ Occasional breast milk substitutes in hospital } \\
\hline Yes & $1.66(1.24-2.23)$ & ns \\
\hline No & 1 & \\
\hline \multicolumn{3}{|l|}{ Pacifier use in hospital } \\
\hline Yes & $1.39(1.02-1.89)$ & ns \\
\hline No & 1 & \\
\hline-2 log likelihood (degrees of freedom) & $1757,85(6)$ & $1145.34(5)$ \\
\hline
\end{tabular}

a Full Breastfeeding

${ }^{\mathrm{b}}$ Any Breastfeeding; ${ }^{\mathrm{b}}$ Adjusted Hazard Ratio;

"Confidence Interval 95\%, "ns" indicates non-significant differences in the model when including the variable.

*After the stepwise method, the final model was developed taking into account the following potential confounding variables: social class, mother's age, parity, delivery type, moment of skin-to-skin contact postpartum, gender and weight of infant and hospital routines like rooming-in practice, professional breastfeeding help, pacifier use, breast milk substitutes and limitation of breastfeeding duration and frequency.

\section{Discussion}

This study reveals an independent effect of the mother's education level, earlier BF experience, participation in maternal education groups and use of pacifiers or breast milk substitutes in the postpartum period on the early cessation of FBF or ABF. The influence of the mother's valuation of earlier $A B F$ experiences had not been mentioned in other similar research yet.

In the sample, the duration of FBF and $A B F$ remains far below the mothers' own expectations and international recommendations. Data for duration of $A B F$ are similar to other studies showing results for $A B F$ duration in groups of Spanish mothers who breastfed since birth ${ }^{(6,13)}$.

The positive influence of the mother's higher education level on the duration of BF has been identified in countless studies ${ }^{(2,4,6,9)}$. The education level is a good proxy of social class $^{(11)}$ and a higher social status has been related with better $\mathrm{BF}$ rates ${ }^{(14)}$. In the analysis, the education level shows to be a more powerful variable 
than social class based on the mother's occupation, with a view to detecting intergroup BF differences.

The variables related to the mothers' earlier experience exert the strongest independent effect on the duration of FBF and $A B F$ in the sample. The results support the hypothesis about a positive relation between the duration of earlier and current BF, as mothers who did not breastfeed an earlier child ceased ABF or FBF faster than those who breastfeed for four months or less, and the latter faster than mothers who breastfed longer. In another Spanish research, previous breastfeeding experience for more than four months was described as a protective factor of $\mathrm{BF}^{(2)}$.

The positive association between the mother's valuation of earlier $\mathrm{BF}$ and the duration of current BF had not been studied to date. Mothers who valued the earlier experience as less possible may have faced more difficulties during the earlier BF experience and, hence, ceased the current BF more easily when new problems arose. Further research is needed to expand on this aspect.

The positive effect of participation in prenatal education sessions has been described earlier (15-16) and another research carried out in Spain had associated the duration of BF with the information professionals offer during pregnancy(6).

In different observation studies, the relation between BF duration and occasional bottles ${ }^{(6,9,15)}$ or pacifier use ${ }^{(5,17)}$ in the postpartum period has been observed, although its direct causal effect on the duration of BF still remains unclear and its use could actually be a symptoms of the appearance of initial BF difficulties ${ }^{(5,18)}$.

Generalization of these study results should be done cautiously, as it cannot be determined whether the mothers who participated in midwifery consultations and were included in the sample were more predisposed to self-care for their health or if they participated in the consultations for other reasons.

The absence of a relation in the sample between FBF or ABF cessation and variables identified in other studies, such as maternal age $\mathrm{e}^{(2,6,15)}$, delivery type $(2,4,6)$ and the infant's birth weight ${ }^{(4)}$ could be explained by the sample's characteristics or size, which makes it difficult to identify risk factors with a lesser impact on BF duration. On the other hand, the variables identified in other studies that were not controlled for in the sample, such as maternal obesity(15), smoking(2,5), mother's attitude towards $\mathrm{ABF}^{(5)}$ and situations after birth, such as $B F$ problems ${ }^{(3,5,17)}$ could also influence the duration of ABF or FBF.

\section{Conclusion}

In conclusion, it is highlighted that (i) the success of $\mathrm{BF}$ is closely linked with the existence of a positive previous experience, which is why prioritizing professional support resources should take into account the group of mothers without earlier BF experience or with a negative earlier experience; (ii) Adequate information supply can be a protective factor of BF and should be accessible, especially for mothers with a lower education level or more difficult access to the necessary information; and, (iii) postpartum interventions to support BF should include the control of hospital routines, such as the use of pacifiers and not medically indicated breast milk substitutes that can influence the early cessation of BF.

\section{Acknowledgements}

The authors are grateful to Ana Mayoral and Esther Abad for their cooperation in data collection. Acknowledgements to Pilar Giner, Lourdes Martínez, Núria Torras and Mireia Ladios for their contributions to the final writing of this article.

\section{References}

1. Cattaneo A, Yngve A, Koletzko B, Guzman LR. Protection, promotion and support of breast-feeding in Europe: current situation. Public Health Nutr. 2005 Feb;8(1):39-46.

2. Ortega García JA, Pastor Torres E, Martínez Lorente I, Bosch Giménez V, Quesada López JJ, Hernández Ramón F, et al. Proyecto Malama en la Región de Murcia (España): medio ambiente y lactancia maternal. An Pediatr (Barc) 2008 May; 68(5):447-53

3. Do Espirito Santo LC, de Oliveira LD, Giugliani ER. Factors associated with low incidence of exclusive breastfeeding for the first 6 months. Birth. 2007 Sep; 34(3):212-9.

4. Hernández Aguilar MT, Muñoz Guillén A, Lasarte Velillas JJ, García Vera C, Díaz Marijuan C, Martín Calama J. La lactancia materna en la Comunidad Valenciana. Análisis multivariante de una encuesta a 6.400 lactantes. Rev Pediatr Atención Primaria 2004; 6(21):19-37.

5. Scott JA, Binns CW, Oddy WH, Graham KI. Predictors of Breastfeeding Duration: Evidence From a Cohort Study. Pediatrics. 2006 April;117(4):e646-55.

6. Estévez González MD, Martell Cebrián D, Medina Santana R, García Villanueva E, Saavedra Santana P. Factores relacionados con el abandono de la lactancia materna. Anales Esp Pediatr 2002 Feb; 56(2):144-50.

7. Britton C, McCormick FM, Renfrew MJ, Wade A, King SE. Apoyo para la lactancia materna (Revisión Cochrane traducida). En: La Biblioteca Cochrane Plus, 2008 Número 1. Oxford: Update Software Ltd. Disponible en: http://www.update-software.com. Traducida de The Cochrane Library, 2007 Issue 4. Chichester, 
UK: John Wiley; 2008.

8. Kramer MS, Chalmers B, Hodnett ED, Sevkovskaya Z, Dzikovich I, Shapiro $S$, et al. Promotion of Breastfeeding Intervention Trial (PROBIT): a randomized trial in the Republic of Belarus. JAMA. 2001 January 24-31; 285(4):413-20.

9. Suárez Gil P, Alonso Lorenzo JC, López Díaz AJ, Martín Rodríguez D, Martínez Suárez MM. Prevalencia y duración de la lactancia materna en Asturias. Gac Sanit 2000; 15(2):104-10.

10. WHO. Indicators for assessing infant and young child feeding practices. [monograph on the Internet]. Ginebra: WHO; 2007 [cited 2009 June 25]. Available from: http://whqlibdoc.who.int/ publications/2008/9789241596664_eng.pdf

11. Grupo de trabajo de la Sociedad Española de Epidemiología y de la sociedad española de Medicina de Familia y Comunitaria. Una propuesta de medida de la clase social. Atención Primaria $2000 ; 25(5): 132-51$.

12. Peat JK, Allen J, Nguyen N, Hayen A, Oddy WH, Mihrshahi $\mathrm{S}$. Motherhood meets epidemiology: measuring risk factors for breast-feeding cessation. Public Health Nutr 2004 Dec; 7(8):1033-7.

13. Rodicio García MM, Abadi Abadi A, Silveira Cancela M,
Rodríguez Sáez MJ, Andrés Andrés A, Vázquez Caruncho M. Tendencia y evolución de la lactancia materna en el norte de Lugo. Acta Pediatr Esp. 2007; 65(1):6-11.

14. Kelly YJ, Watt RG. Breast-feeding initiation and exclusive duration at 6 months by social class - results from the Millennium Cohort Study. Public Health Nutr. 2005; 8(4):417-22.

15. Forster DA, McLachlan HL, Lumley J. Factors associated with breastfeeding at six months postpartum in a group of Australian women. Int Breastfeed J. 2006 Oct 12; 1:18.

16. Su LL, Chong YS, Chan YH, Chan YS, Fok D, Tun KT, et al. Antenatal education and postnatal support strategies for improving rates of exclusive breast feeding: randomised controlled trial. BMJ. 2007 September 22; 335(7620):574-5.

17. Carvalhaes MABL, Parada CMGL, da Costa MP. Factors associated with exclusive breastfeeding in children under four months old in Botucatu-SP, Brazil. Rev. Latino-Am. Enfermagem 2007 January-February;15(1):62-9.

18. Szajewska H, Horvath A, Koletzko B, Kalisz M. Effects of brief exposure to water, breast-milk substitutes, or other liquids on the success and duration of breastfeeding: a systematic review. Acta Paediatr. 2006 February; 95(2):145-52.

Received: Jun. 6 2009

Accepted: Nov. 16 2009 